\title{
Heavy metal content in the green fodder of field pea/oat mixtures destined for cattle feed
}

\author{
Anna Plaza • Barbara Gąsiorowska • \\ Emilia Rzążewska (iD
}

Received: 21 March 2019 /Accepted: 10 October 2019/Published online: 26 October 2019

(C) The Author(s) 2019

\begin{abstract}
The objective of the study was to establish the effect of component share in mixtures and harvest date on concentrations of selected heavy metals in the green fodder of field pea, oat, and their mixtures. The research hypothesis assumed that the cultivation of peas and oats in pure sowing, and in mixtures will also allow to choose combinations from which the forage will have the lowest content of heavy metals. Field research was conducted at the Zawady Experimental Farm (52 $03^{\circ}$ $39^{\prime \prime} \mathrm{N}, 22^{\circ} 33^{\prime} 80^{\prime \prime} \mathrm{E}$ ) which belongs to Siedlce University of Natural Sciences and Humanities. Two factors were tested in the study: I-component share in the mixture: field pea-pure stand $100 \%$, oat - pure stand $100 \%$, field pea $75 \%+$ oat $25 \%$, field pea $50 \%+$ oat $50 \%$, field pea $25 \%+$ oat $75 \%$; II-harvest date: field pea flowering stage, field pea flat pod stage. Plant material was sampled to determine the following elements: $\mathrm{Cu}, \mathrm{Zn}, \mathrm{Cd}, \mathrm{Pb}, \mathrm{Cr}$, and $\mathrm{Ni}$. The results of the study demonstrated that field pea grown in pure stand had the highest copper and zinc contents, and the lowest chromium and nickel contents. Field pea mixed with oat significantly reduced heavy metal content in green fodder. Cadmium and lead contents in the green fodder of field pea/oat mixtures were too low to be determined by means of the spectrometer Perkin Elmer Optima 8300. Regular checks of heavy metal contents are
\end{abstract}

\footnotetext{
A. Płaza • B. Gąsiorowska • E. Rzążewska $(\bowtie)$

Siedlce University of Natural Sciences and Humanities, Faculty of Agrobioengineering and Animal Husbandry, Agriculture and Gardening Institutes, Research Team of Agrotechnology, Prusa 14, 08-110 Siedlce, Poland e-mail: emilia.rzazewska@uph.edu.pl
}

recommended in spite of their low amounts in the green fodder of field pea/oat mixtures.

Keywords Pisum sativum - Avena sativa $\cdot$ Mixture . Harvest date $\cdot$ Heavy metals

\section{Introduction}

Green fodder produced from legume/cereal mixtures is a valuable source of dairy cattle feed, providing it has a beneficial chemical composition, including a low concentration of heavy metals (Ociepa-Kubicka and Ociepa 2012; Chandra Sekhar et al. 2002). Thus, it is necessary to check its safety in terms of impurities present in feeds, including above-ground parts. Monitoring of toxic and potentially toxic elements is one of the most important aspects of maintaining feed quality. Transfer of heavy metals from soil to animal body occurs through plants which are the most important link in the food chain. Heavy metals contaminating the soil hamper the development of soil microorganisms. Negative correlations between the biomass of microorganisms and $\mathrm{Pb}, \mathrm{Zn}$, and $\mathrm{Cu}$ contents in soils contaminated with metals have been reported by Ociepa-Kubicka and Ociepa 2012 as well as Sharma et al. 2004. Heavy metal uptake by plants occurs through the rooting system and leaf blades. Heavy metals display various harmful effects. Lead, cadmium, chromium, and nickel are perceived as toxic metals but zinc and copper are microelements which are harmful when present in excess whereas 
their low amounts are necessary for the appropriate functioning of the body (Ali and Al-Qahtani 2012; Abdulmojeed and Abdulrahman 2011; Sharma et al. 2004). The following plants have the greatest capacity to accumulate heavy metals: lettuce, cabbage, beetroot, carrot, spinach, and potato, whereas the uptake by tomato, cucumber, leguminous, and cucurbitaceous vegetables as well as fruit is much lower. Cereal grain, and as a result green fodder, can be contaminated as well (Ali and Al-Qahtani 2012; Sobucola et al. 2010). Too high levels of metals in plants destined for animal feed may lead to animalderived products being contaminated by the metals. Legumes are of particular importance as, when mixed with cereals, they reduce the uptake of heavy metals from the soil and limit their concentration in the soil (Dabney et al. 2001; Snapp et al. 2005). There is a perceptible lack of studies on the aforementioned subject. Thus, the need arises to undertake research in this area to monitor heavy metals in animal feed. The objective of the study reported here was to determine the effect of component share in the mixture and harvest date on the concentration of selected heavy metals in the green fodder of field pea, oat, and their mixtures.

\section{Materials and methods}

Field research was conducted in the years 2010 to 2012 at the Zawady Experimental Farm (52 03' 39" $\mathrm{N}, 22^{\circ} 33^{\prime} 80^{\prime \prime} \mathrm{E}$ ) which belongs to Siedlce University of Natural Sciences and Humanities. The experimental soil was Albic Luvisol (Arenic). The concentration of ele-

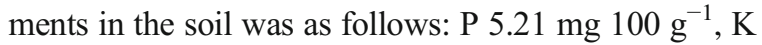

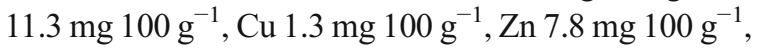
$\mathrm{Pb}<15.1 \mathrm{mg} 100 \mathrm{~g}^{-1}, \mathrm{Cd} 0.10 \mathrm{mg} 100 \mathrm{~g}^{-1}, \mathrm{Cr}<12.6 \mathrm{mg}$

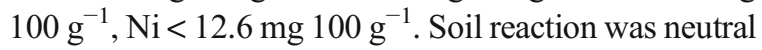
and humus content amounted to $1.39 \%$. The experimental design was a split-block arrangement with three replicates. The area of plots under winter wheat was $30 \mathrm{~m}^{2}(5 \mathrm{~m} \times 6 \mathrm{~m})$, and the harvested area was $20 \mathrm{~m}^{2}$ $(4 \mathrm{~m} \times 5 \mathrm{~m})$. Two factors were tested in the study: Icomponent share in the mixture: field pea-pure stand $100 \%$, oat - pure stand $100 \%$, field pea $75 \%$ + oat $25 \%$, field pea $50 \%$ + oat $50 \%$, field pea $25 \%$ + oat $75 \%$; IIharvest date: field pea flowering stage, field pea flat green pod stage. The species proportion in a mixture was established in relation to the number of seeds planted in pure stands, that is 560 grains of oat and 120 grains of field pea $\mathrm{m}^{2}$. The following sowing rates were used: field pea $170 \mathrm{~kg} \mathrm{ha}^{-1}$, oat $180 \mathrm{~kg} \mathrm{ha}^{-1}$, field pea $128 \mathrm{~kg} \mathrm{ha}^{-1}+$ oat $45 \mathrm{~kg} \mathrm{ha}^{-1}$, field pea $85 \mathrm{~kg} \mathrm{ha}^{-1}$ + oat $90 \mathrm{~kg} \mathrm{ha}^{-1}$, field pea $43 \mathrm{~kg} \mathrm{ha}{ }^{-1}$ + oat $135 \mathrm{~kg}$ $\mathrm{ha}^{-1}$.

In all the study years, the mixtures were preceded by winter triticale. Phosphorus and potassium fertilisers were applied in autumn and their rates, $35.2 \mathrm{~kg} \mathrm{ha}^{-1} \mathrm{P}$ in the form of granular triple superphosphate and $99.6 \mathrm{~kg} \mathrm{ha}{ }^{-1} \mathrm{~K}$ in the form of $60 \%$ potassium salt, depended on soil chemical composition. In spring, nitrogen fertiliser, at the rate of $30 \mathrm{~kg} \mathrm{ha}^{-1} \mathrm{~N}$ in the form of ammonium nitrate, was applied preplant to all the plots, excluding the units assigned to field pea grown in pure stand. At the stage of stem elongation, additional $\mathrm{N}$ was applied (50 kg ha ${ }^{-1}$ for oat and $30 \mathrm{~kg} \mathrm{ha}^{-1}$ for field pea/oat mixtures). Field pea and oat seeds were planted in early April as described for the first experimental factor. Plants were harvested in late June and early July. During harvest of mixtures, fresh matter samples were taken from each plot to determine microelements. $\mathrm{Cu}$, $\mathrm{Zn}, \mathrm{Cd}, \mathrm{Pb}, \mathrm{Cr}$, and $\mathrm{Ni}$ contents were determined by means of inductively coupled plasma optical emission spectrometry (ICP-OES) using the spectrometer Perkin Elmer Optima 8300.

Each characteristic tested was subjected to analysis of variance suitable for the split-block design. When significant sources of variation were confirmed, their means were separated using Tukey test. Calculations were performed in MS Excel 12.0.

The years of the study were characterised by significantly changeable weather conditions (Table 1). In 2010, mean air temperatures during the growing period fluctuated around the mean long-term temperatures. The precipitation totals, except for April, were higher than the mean long-term total precipitation. This year should be regarded as favourable for the cultivation of mixtures of field peas with oat. In 2011, the mean monthly air temperatures slightly differed from the mean long-term temperatures. However, the rainfall totals were lower than the mean long-term totals, except for July, where the recorded precipitation was $120.2 \mathrm{~mm}$. In 2012, the average air temperature and total precipitation fluctuated around the longterm average. The lowest content of heavy metals was recorded in the green mass of mixtures of pea and oats in 2010, with the highest rainfall in June and July, and the highest content of heavy metals in 2012 with the lowest rainfall in July and throughout the growing season. 


\section{Results and discussion}

Copper content in the green matter of field pea/oat mixtures was significantly affected by the experimental factors and their interaction (Table 2). The highest copper content (4.660 mg kg-1 d.m.) was recorded in field pea grown in pure stand, it being the lowest in oat (3.811 mg kg-1 d.m.). Also, Woźniak and Soroka (2016), Jarecki and Bobrecka-Jamro (2015), and Ali and Al-Qahtani (2012) observed a lower copper content in cereal grain rather than soy bean seed. In the experiment reported here, copper content in field pea, although higher than in oat, did not exceed the WHO/ FAO standards, such feed being safe for animals. It should be emphasised that more copper was accumulated by legumes, although its amounts were low and did not pose a threat to human and animal health (Adefarati et al. 2017; Chandra Sekhar et al. 2002; Zarcinas et al. 2004). Plants take up small amounts of copper which, transferred to animals eating the plants, is necessary for the body because it participates in oxidation-reduction processes where it is a component of the coenzyme, and regulates metabolism, iron transportation, and collagen metabolism (Cabrera et al. 2003). In the present study, copper content in field pea/oat mixtures was significantly lower than in field pea grown in pure stand. The lowest $\mathrm{Cu}$ concentration was recorded in the mixture composed of the following respective shares of field pea and oat: $50+50 \%$ and $25+75 \%$. A similar relationship was observed by Trąba and Wolański (2003) who reported that copper content in the dry matter of a grass/ legume mixture was about twice as low as in legumes grown in pure stand. In the study reported here, harvest date had a significant influence on copper content in the green fodder of field pea/oat mixtures. A higher concentration of copper was recorded in field pea/oat mixtures harvested at the stage of field pea flowering compared with the stage of flat green pod. Research by Ladipo and Doherty (2011) as well as Abdulmojeed and Abdulrahman (2011) demonstrated that copper uptake by leafy vegetables is affected by such factors as climate, precipitation, concentration of heavy metals in soil, soil type, and maturity of plants at harvest. Fytianos et al. (2001), Demirezen and Aksoy (2006), and Muchuweti et al. (2006) have claimed that plants harvested at earlier development stages contain more copper. In the present study, an interaction between the experimental factors was confirmed indicating that field pea grown in pure stand and harvested at flowering contained the highest amount of copper, it being the lowest in pure stand oat harvested at the stage of flat green pod. All the test field pea/oat mixtures harvested at this stage had a lower copper content compared with field pea cultivated in pure stand and harvested at the flat green pot stage.

Statistical analysis demonstrated a significant effect of the experimental factors and their interaction on zinc content in the green fodder of field pea/oat mixtures (Table 3). Zinc plays a major role in plant metabolism. Plant growth and development are hindered by both zinc shortage and excess (Ociepa-Kubicka and Ociepa 2012). Although zinc is necessary in plant nutrition, plants growing in a polluted environment may accumulate high amounts of this element, which can pose a serious threat to the health of people and animals (YuWei et al. 2013; Sharma et al. 2004; Srinivas et al. 2002). In the present study, the highest zinc content was recorded in field pea grown in pure stand, it being the lowest in oat. Also Adefarati et al. (2017) recorded a similar zinc content in green peas. However, the values are lower than standards set by WHO/FAO and are not harmful to humans or animals. According to Fytianos et al. (2001), Demirezen and Aksoy (2006), and Ali and Al-Qahtani (2012), zinc content in cereals is lower compared with beans and peas. In the experiment reported here, field pea mixed with oat increased zinc content in the green fodder of mixtures, the values being lower than in field pea but higher than in oat. This finding corresponds to values reported by Goliński et al. (2007) and Szpunar-Krok et al. (2009). Harvest date had a significant effect on zinc content in the green fodder of field pea/oat mixtures. A higher concentration of this element was recorded in mixtures harvested at the stage of field pea flat green pod compared with the flowering stage. A delay in harvest was followed by an increase in the plant content of zinc. As zinc is a microelement, its higher amount in green fodder is of great importance for human and animal health (Płaza et al. 2018; Adefarati et al. 2017; Chandra Sekhar et al. 2002; Zarcinas et al. 2004). In the present study, an interaction between the experimental factors was confirmed. The highest zinc content was recorded in the green fodder of field pea grown in pure stand and harvested at the stage of flat green pot, it being the lowest in oat grown in pure stand and harvested at the stage of field pea flowering. Of the examined mixtures, the highest concentration of zinc was determined in field pea/oat mixtures whose component shares were $75+$ 
Table 1 Pluvio-thermal conditions in the growing season of pea and oat mixtures in 2010-2012 according to the Meteorological Station in RSD Zawady

\begin{tabular}{|c|c|c|c|c|c|}
\hline \multirow[t]{2}{*}{ Year } & \multicolumn{4}{|c|}{ Month } & \multirow[t]{2}{*}{ Mean } \\
\hline & April & May & June & July & \\
\hline \multicolumn{6}{|l|}{ Temperature ${ }^{\circ} \mathrm{C}$} \\
\hline 2010 & 8.9 & 14.0 & 17.4 & 21.6 & 15.5 \\
\hline 2011 & 10.1 & 13.4 & 18.1 & 18.3 & 15.0 \\
\hline 2012 & 8.9 & 14.6 & 16.3 & 20.7 & 15.1 \\
\hline Long-term mean 1990-2005 & 8.2 & 14.2 & 17.6 & 19.7 & 14.9 \\
\hline \multicolumn{6}{|l|}{ Precipitation, mm } \\
\hline 2010 & 10.7 & 93.2 & 62.6 & 77.0 & 243.5 \\
\hline 2011 & 31.0 & 36.1 & 39.1 & 120.2 & 226.4 \\
\hline 2012 & 29.9 & 53.4 & 76.2 & 43.0 & 202.5 \\
\hline Long-term mean 1990-2005 & 37.4 & 47.1 & 48.1 & 65.5 & 198.1 \\
\hline
\end{tabular}

$25 \%$ and $50+50 \%$, and which were harvested at the stage of field pea flat green pot.

Lead and cadmium contents were insignificantly affected by the experimental factors and their concentrations in the green fodder of field pea/oat mixtures were too low to be determined by means of the emission spectrometer Perkin Elmer Optima 8300. Thus, they did not exceed the standards set for green fodder in the Official Journal of the European Union (2013). It was due to the fact that fields where the research was conducted were well away from roads and the green matter of field pea/oat mixtures was a safe cattle feed. The air and soil are major sources of heavy metals for plants (Adefarati et al. 2017;
Brigide et al. 2014). Despite low $\mathrm{Cd}$ and $\mathrm{Pb}$ contents in the green fodder of field pea/oat mixtures determined in the present study, it is necessary to continually monitor and check plant-derived feeds in terms of their heavy metal content.

Statistical analysis confirmed a significant effect of the experimental factors and their interaction on chromium content in the green fodder of field pea/ oat mixtures (Table 4). The lowest chromium content was recorded in oat cultivated in pure stand, it being the lowest in field pea cultivated in pure stand. Field pea mixed with oat significantly reduced chromium content in green fodder. Some studies demonstrated excessive $\mathrm{Cr}$ amounts in

Table 2 Copper content in the green fodder of field pea/oat mixtures (means across 2010-2012), $\mathrm{mg} \mathrm{kg}^{-1}$ d.m.

\begin{tabular}{|c|c|c|c|}
\hline \multirow[t]{2}{*}{ Component share in the mixture, $\%$} & \multicolumn{2}{|l|}{ Harvest date } & \multirow[t]{2}{*}{ Means } \\
\hline & Field pea flowering stage & Field pea flat green pod stage & \\
\hline Field pea in pure stand $100 \%$ & 5.072 & 4.248 & 4.660 \\
\hline Oat in pure stand $100 \%$ & 4.245 & 3.376 & 3.811 \\
\hline Field pea $75 \%+$ oat $25 \%$ & 4.693 & 3.914 & 4.304 \\
\hline Field pea $50 \%+$ oat $50 \%$ & 4.458 & 3.708 & 4.083 \\
\hline Field pea $25 \%+$ oat $75 \%$ & 4.207 & 3.537 & 3.872 \\
\hline Means & 4.535 & 3.757 & - \\
\hline \multicolumn{4}{|l|}{$\mathrm{LSD}_{0.05}$} \\
\hline Component share in the mixture & & & 0.212 \\
\hline Harvest & & & 0.130 \\
\hline Interaction & & & 0.272 \\
\hline
\end{tabular}


Table 3 Zinc content in the green fodder of field pea/oat mixtures (means across 2010-2012), $\mathrm{mg} \mathrm{kg}^{-1}$ d.m.

\begin{tabular}{|c|c|c|c|}
\hline \multirow[t]{2}{*}{ Component share in the mixture, $\%$} & \multicolumn{2}{|l|}{ Harvest date } & \multirow[t]{2}{*}{ Means } \\
\hline & Field pea flowering stage & Field pea flat green pod stage & \\
\hline Field pea in pure stand $100 \%$ & 41.08 & 56.37 & 48.73 \\
\hline Oat in pure stand $100 \%$ & 29.08 & 38.23 & 33.66 \\
\hline Field pea $75 \%+$ oat $25 \%$ & 39.23 & 50.32 & 44.78 \\
\hline Field pea $50 \%+$ oat $50 \%$ & 36.97 & 48.78 & 42.88 \\
\hline Field pea $25 \%+$ oat $75 \%$ & 33.12 & 40.54 & 36.83 \\
\hline Means & 35.90 & 46.85 & - \\
\hline \multicolumn{4}{|l|}{$\mathrm{LSD}_{0.05}$} \\
\hline Component share in the mixture & & & 2.31 \\
\hline Harvest date & & & 1.43 \\
\hline Interaction & & & 3.12 \\
\hline
\end{tabular}

cereals and rice (Akinyele and Shokunbi 2015; Pirsaheb et al. 2016; Brigide et al. 2014; Ali and Al-Qahtani 2012; Abdulmojeed and Abdulrahman 2011). In contrast, legumes are characterised by a lower concentration of chromium (Brigide et al. 2014; Akinyele and Shokunbi 2015). In the current study, there was confirmed a significant effect of harvest date on chromium content in the green fodder of field pea/oat mixtures. A higher concentration of this element was recorded in the field pea/oat mixture harvested at the stage of field pea flat green pod versus the flowering stage, which can be explained by the fact that plants harvested at later dates take up more chromium from the soil (Adefarati et al. 2017). However, in the experiment discussed here, chromium content in the green fodder of field pea/oat mixtures harvested at the stage of flat green pod was not high and posed no threat to animals. Similar findings were reported by Adefarati et al. (2017), Ladipo and Doherty (2011), and Sobucola et al. (2010) who demonstrated that chromium content in the plants they tested (cereals and legumes) did not exceed WHO/FAO standards. Chromium levels in plants are affected by their maturity at harvest. Small amounts of chromium are essential for life as the element plays a significant role in the metabolic transformations of glucose, some proteins, and fats (Ociepa-Kubicka and Ociepa 2012; Sobucola et al. 2010). In the study presented here, an interaction between the

Table 4 Chromium content in the green fodder of field pea/oat mixtures (means across 2010-2012), $\mathrm{mg} \mathrm{kg}^{-1}$ d.m.

\begin{tabular}{|c|c|c|c|}
\hline \multirow[t]{2}{*}{ Component share in the mixture, $\%$} & \multicolumn{2}{|l|}{ Harvest date } & \multirow[t]{2}{*}{ Means } \\
\hline & Field pea flowering stage & Field pea flat green pod stage & \\
\hline Field pea in pure stand $100 \%$ & 1.353 & 1.696 & 1.525 \\
\hline Oat in pure stand $100 \%$ & 3.560 & 6.914 & 5.237 \\
\hline Field pea $75 \%+$ oat $25 \%$ & 1.874 & 3.423 & 2.649 \\
\hline Field pea $50 \%+$ oat $50 \%$ & 2.157 & 4.072 & 3.115 \\
\hline Field pea $25 \%+$ oat $75 \%$ & 2.981 & 5.340 & 4.161 \\
\hline Means & 2.385 & 4.289 & - \\
\hline \multicolumn{4}{|l|}{$\mathrm{LSD}_{0.05}$} \\
\hline Component share in the mixture & & & 0.623 \\
\hline Harvest date & & & 0.249 \\
\hline Interaction & & & 0.872 \\
\hline
\end{tabular}


Table 5 Nickel content in the green fodder of field pea/oat mixtures (means across 2010-2012), $\mathrm{mg} \mathrm{kg}^{-1}$ d.m.

\begin{tabular}{|c|c|c|c|}
\hline \multirow[t]{2}{*}{ Component share in the mixture, $\%$} & \multicolumn{2}{|l|}{ Harvest date } & \multirow[t]{2}{*}{ Means } \\
\hline & Field pea flowering stage & Field pea flat green pod stage & \\
\hline Field pea in pure stand $100 \%$ & 1.557 & 1.972 & 1.765 \\
\hline Oat in pure stand $100 \%$ & 3.282 & 5.705 & 4.494 \\
\hline Field pea $75 \%+$ oat $25 \%$ & 1.926 & 2.747 & 2.337 \\
\hline Field pea $50 \%+$ oat $50 \%$ & 2.215 & 3.538 & 2.877 \\
\hline Field pea $25 \%+$ oat $75 \%$ & 2.743 & 4.216 & 3.480 \\
\hline Means & 2.345 & 3.636 & - \\
\hline \multicolumn{4}{|l|}{$\mathrm{LSD}_{0.05}$} \\
\hline Component share in the mixture & & & 0.593 \\
\hline Harvest date & & & 0.189 \\
\hline Interaction & & & 0.732 \\
\hline
\end{tabular}

experimental factors was confirmed. The highest chromium content was recorded in the green fodder of field pea grown in pure stand and harvested at the flowering stage or the flat green pod stage, and in field pea/oat mixtures whose component shares were as follows: $75+25 \%$ and $50+50 \%$, and which were harvested at the stage of field pea flowering. The highest chromium content was determined in oat grown in pure stand and harvested at the stage of field pea flat green pod.

Nickel content in the green fodder of field pea mixed with oat was significantly affected by the experimental factors and their interaction (Table 5). The lowest nickel content was recorded in field pea grown in pure stand, it being the highest in oat cultivated in pure stand. Ni levels determined in the present study did not exceed WHO/FAO standards (Adefarati et al. 2017). Small amounts of nickel are necessary for plant growth and development (Akinyele and Shokunbi 2015), the element being toxic when present in excessive amounts (Cabrera et al. 2003). It should be stressed that, in the study reported here, field pea mixed with oat contributed to a decline in the green fodder content of nickel. Harvest date significantly affected Ni content in the green fodder of field pea/oat mixtures. Nickel content was lower in plants harvested at the stage of field pea flowering compared with the stage of flat green pod. Also, Ladipo and Doherty (2011) as well as Sobucola et al. (2010) reported that nickel content in plants was influenced by their maturity stage at harvest. In the present study, interaction between the experimental factors was confirmed. The lowest nickel content was determined in the green fodder of pure stand field pea harvested at the flowering stage and the stage of flat green pod, and in field pea/oat mixtures with the following shares of components: $75+25 \%$ and $50+50 \%$ harvested at the stage of field pea flowering. Nickel content was the highest in oat harvested at the stage of field pea flat green pod.

\section{Conclusions}

Field pea grown in pure stand had the highest copper and zinc contents, and the lowest chromium and nickel contents. Field pea mixed with oat contributed to a significant decline in the green fodder content of heavy metals.

Field pea/oat mixtures harvested at the stage of field pea flowering contained more copper but less zinc, chromium, and nickel compared with mixtures harvested at the stage of field pea flat green pod.

Cadmium and lead contents in the green fodder of field pea mixed with oat were insignificantly affected by the experimental factors, and were too low to be determined by means of the emission spectrometer Perkin Elmer Optima 8300.

Green fodder of field pea mixed with oat, whether harvested at the flowering stage or the stage of field pea flat green pod, was safe for cattle because it did not contain excessive amounts of heavy metals. 
Despite a low heavy metal content in the green fodder of field pea mixed with oat, continual monitoring of these elements is recommended.

Open Access This article is distributed under the terms of the Creative Commons Attribution 4.0 International License (http:// creativecommons.org/licenses/by/4.0/), which permits unrestricted use, distribution, and reproduction in any medium, provided you give appropriate credit to the original author(s) and the source, provide a link to the Creative Commons license, and indicate if changes were made.

\section{References}

Abdulmojeed, O. L., \& Abdulrahman, A. A. (2011). Analysis of heavy metals found in vegetables from some cultivated irrigated gardens in the Kano metropolis, Nigeria. Journal of Environmental chemistry and Ecotoxicology, 3(6), 142-148.

Adefarati, O., Adedeji, P. O., \& Ajala, O. (2017). Determination of heavy metal levels in green pea (Pisum sativum) a case study of selected markets in Abuja, FCT. American Journal of Innovative Research and Applied Sciences. Accessed date 31 Oct 2017. www.american-jiras.com.

Akinyele, I. O., \& Shokunbi, O. S. (2015). Concentrations of Mn, $\mathrm{Fe}, \mathrm{Cu}, \mathrm{Zn}, \mathrm{Cr}, \mathrm{Cd}, \mathrm{Pb}, \mathrm{Ni}$ in selected Nigerian tubers, legumes and cereals and estimates of the adult dally intakes. Food Chemistry, 173, 702-708. https://doi.org/10.1016/j. foodchem.2014.10.098.

Ali, M., \& Al-Qahtani, K. M. (2012). Assessment of some heavy metals in vegetables, cereals and fruits in Saudi Arabian markets. Egyptian Journal of Aquatic Research., 38, 31-37. https://doi.org/10.1016/j.ejar.2012.08.002.

Brigide, P., Canniatti-Brazaca, S. G., \& Silva, M. O. (2014). Nutritional characteristics of biofortified common beans. Food Science and technology (Campinas), 34(3), 493-500. https://doi.org/10.1590/1678-457x.6245.

Cabrera, C., Lloris, F., Gimenez, R., Olalla, M., \& Lopez, C. (2003). Mineral content in legumes and nuts: contribution to the Spanish dietary intake. The Science of the Total Environment, 308, 1-14.

Chandra Sekhar, K., Rajni Supriya, K., Kamala, C. T., Chary, N. S., Negeswara Rao, T., \& Anjaneyulu, Y. (2002). Speciation, accumulation of heavy metals in vegetation grown on sludge amended soils and their transfer to human food chain - a case study. Toxicological and Environmental Chemistry, 82, 33-34. https://doi. org/10.1080/716067220.

Dabney, S. M., Delgado, J. A., \& Reeves, D. W. (2001). Using winter cover crops to improve soil and water quality. Community of Soil Science Plant Analysis, 32(7-8), 12211250. https://doi.org/10.1081/CSS-100104110.

Demirezen, D., \& Aksoy, A. (2006). Heavy metal levels in vegetables in Turkey are within safe limits for $\mathrm{Cu}, \mathrm{Zn}$, $\mathrm{Ni}$ and exceeded for $\mathrm{Cd}$ and $\mathrm{Pb}$. Journal of Food Quality, 29, 252-265. https://doi.org/10.1111/j.17454557.2006.00072.x.
Fytianos, K., Katsianis, G., Triantafyllou, P., \& Zachariadis, G. (2001). Accumulation of heavy metals in vegetables grown in an industrial area in relation to soil. Bulletin of Environment Contamination and Toxicology, 67, 423-430.

Goliński, P., Spychalski, W., Golinska, B., \& Krochnke, D. (2007). Effect of the cultivar Trifolium repens L. on the mineral composition of the grassy-legume meadows. Grassland Science in Poland, 10, 49-58.

Jarecki, W., \& Bobrecka-Jamro, D. (2015). Effect of fertilization with nitrogen and seed inoculation with Nitragina on seed quality of soya bean (Glycine max (L.) Merrill). Acta Scientarum Polonorum Agricultura, 14(3), 51-59.

Ladipo, M. K., \& Doherty, V. F. (2011). Heavy metal levels in vegetables from selected markets in Lagos, Nigeria. African Journal of Food Science and Technology, 2(1), 018-021.

Muchuweti, M., Birkett, J. W., Chinyanga, E., Zvauya, R., Scimshaw, M. D., \& Lester, J. N. (2006). Heavy metal content of vegetables irrigated with mixtures of wastewater and sewage sludge in Zimbabwe: implications for human health. Agriculture, Ecosystems and Environment, 112, 41-48.

Ociepa-Kubicka, A., \& Ociepa, E. (2012). Toxic effects of heavy metals on plants, animals and humans. Engineering and Protection of Environment, 15(2), 169-180.

Official Journal of the European Union. Commission Regulation (EU) No 1275/2013 of 6 December 2013 amending Annex I to Directive 2002/32 / EC of the European Parliament and of the Council as regards maximum levels for arsenic, cadmium, lead, nitrates, volatile mustard oil and harmful botanical impurities.

Pirsaheb, M., Fattahi, N., Sharafi, K., Khamotian, R., \& Atafar, Z. (2016). Essential and toxic heavy metals in cereals and agricultural products marked in Kermanshah, Iran, and human health risk assessment. Food Adoitives and Contaminants: Part B, 9(1), 15-20. https://doi.org/10.1080 /19393210.2015.1099570.

Płaza, A., Górski, R., \& Rzążewska, E. (2018). Micronutrient contents in the green mass of mixtures of blue lupine with spring rye depending on proportion of components and time of harvesting. Acta Scientiarum Polonorum Agricultura, 17(2), 71-79.

Sharma, O. P., Bangar, K. S., Jain, R., \& Sharma, P. K. (2004). Heavy metals accumulation in soil irrigated by municipal and industrial effluent. Journal of Environmental Science and Engineering, 46(1), 65-73.

Snapp, S. S., Swinton, S. M., Labarta, R., Mutch, D., Black, J. R., Leep, R., Nyiraneza, J., \& O’Neil, K. (2005). Evaluating cover crops for benefits, costs and performance within cropping system niches. Agronomy Journal, 97, 322-332. https://doi.org/10.2134/agronj2005.0322.

Sobucola, O. M., Adeniran, A. A., Odedairo, O., \& Kajihausa, E. (2010). Heavy metal levels of some fruits and leafy vegetables from selected markets in Lagos, Nigeria. African Journal of Food Science, 4(2), 389-393.

Srinivas, N., Vinod Kumar, B., \& Suresh Kumar, K. (2002). Lead pollution in roadside plant in Visakhapatnam. Journal of Environmental Studies and Policy, 5(1), 63-68.

Szpunar-Krok, E., Bobrecka-Jamro, D., Tobiasz-Salach, R., \& Kubit, P. (2009). Chemical composition of naked grains oat 
and faba bean seeds in pure sowing and mixtures. Fragmenta Agronomica, 26(2), 152-157.

Trąba, C., \& Wolański, P. (2003). Some aspects of fodder value of papilionaceous plants occuring in sward of seminatural meadows and pastures. Biulletin IHAR, 225, 73-79.

Woźniak, A., \& Soroka, M. (2016). Quality and chemical composition of cereal grains in different agro ecological conditions. Praci Naukovogo Tovaristoa, 70-78.

Yu-Wei, L., Wei-Hua, X., Xiao-Xiao, J., Qian, W., \& Yi-Jian, H. (2013). Effects of germination on iron, zinc, calcium, manganese, and copper availability from cereals. CyTaJournal of Food, 12(1), 22-26.

Zarcinas, B. A., Ishak, C. F., McLaughlin, M. J., \& Cozens, G. (2004). Heavy metals in soils and crops in Southeast Asia 1. Peninsular Malaysia, Environmental Geochemistry and Health, 26, 343-357. https://doi.org/10.1080 /19476337.2013.782071.

Publisher's note Springer Nature remains neutral with regard to jurisdictional claims in published maps and institutional affiliations. 